\title{
Local and Community Well-Being through Community Based Tourism - A Study of Transformative Effect
}

\author{
Rojan Baniya \\ Asst. Prof., Kathmandu University School of Management, Nepal \\ rojan@kusom.edu.np \\ Unita Shrestha \\ Kathmandu University School of Management, Nepal \\ Mandeep Karn \\ Kathmandu University School of Management, Nepal
}

\begin{abstract}
Poverty alleviation through community development is well-accepted agenda throughout the globe. One of the recognized tools for such community development endeavors has been community-based tourism. Not only an atecendent of development, community based tourism can have transformative effect on the individual, community and society as a whole, contributing to momentous transformative service movement. This formed the basis of this study. The research focuses primarily in two communities based tourism. Although the research is conducted at two different locations of Nepal, this study's findings can help guide other similar programs. The findings of the study are encouraging, firstly, it shows CBT can have transformative effect on individual, community and society as a while-people involved in CBThave better individual wellbeing, with satisfaction in their life and better community attachment. In terms of financial wellbeing and psychological needs, CBT seems to fulfill these requirements. Then secondly, it has identified the reasons behind failure of CBT as deficiency in proper mechanism, insufficient scope of coverage, lack of local engagement and empowerment On the positive side, CBT has been successful in stimulating local economy in terms of tourist in flow, enhance the historical heritage, culture, traditions etc., promoting local tradition, generating income promoting local entrepreneurship and produces. The economic impact of CBT is found to be significant. And
\end{abstract}


thirdly based on the outcomes a strong advocacy for CBT is proposed, and this study stands as an attempt to contribute to TSR movement. This research positively links transformative service and community-based tourism together, which has strong future implication.

Keywords: Community based tourism, trans-formative effect, community well-being, individual well-being, quality of life

\section{Introduction}

Academic research has long been questioned regarding its relevance to the society (Davis, Ozanne, \& Hill, 2016). Attention was drawn to the pertinnent issue of customer and societaly well being. With much of the focus of past researches of top journals being on organizational bottom line, recently criticism has arose for scholarly acts not giving enough attention to more meaningful things like quality of life, well being etc. (Mick et al., 2012). In his presidential address, David Mick (2006) called for consumer research to be more than 'for profitability' rather "investigations that are framed by a fundamental problem or opportunity, and that strive to respect, uphold, and improve life in relation to the myriad conditions, demands, potentialities, and effects of consumption." Since then many scholars have taken transformative consumer research as a movement for betterment. The service marketing area could not remain unaffected by this change. Evidently, our life and our wellbeing as individuals, employees, families, and communities revolves around services we consume on daily basis, thus with same notion of transformative consumer research, came in existence transformative service and its subsequent researches, conceptualized by Rosenbaum et al. in 2011. In current context, transformative service research (TSR) has taken shape that without any confirm for academic discipline, it seeks out to understand the relationship between service and well being; more specifically focusing on creating "uplifting changes" at improving lives at all levels (Anderson \& Ostrom, 2015). This study seeks to understand the transformative effect of Community Based Tourism (CBT) on service providers, locals and employees working for it.

With estimated US\$919 billion in export earnings in 2010, (UNWTO, 2011), the economic relevance of tourism industry is unpredented. United Nations World Tourism Organisation Annual Report 2012 (UNWTO, 2013) shares that tourism generates one in every 11 jobs across the globe and has remained one of the largest employers. Furthermore, the UNWTO (2013) also identifies that poverty reduction is a major challenge globally, more acute in developing nation like Nepal, and confirms tourism as among the most feasible and sustainable economic development choice. Evidently, tourism also offers alternatives to some poor regions of the world, especially those blessed with rich cultural and natural assets like Nepal, offering tourists a variety of reasons to visit these under-developed regions (Spenceley \& Meyer, 2012). 
Thus, the concept of community-based tourism has become prevalent in many parts of the world and in Nepal too.

There are several endeavors to enhance the livelihood of rural communities of developing countries and one of the tried methods is community-based tourism. It is a reasonable argument that the local resources leading to tourism should firstly benefit the involved being, family and community. With two direct fundamentals i.e. community participations and locals being direct beneficiaries, community based tourism has been popular over past three decades (Goodwin \& Santilli, 2009). In terms of the final outcome, Brohman, in 1996 shared "Community-based tourism development would seek to strengthen institutions designed to enhance local participation and promote the economic, social and cultural well-being of the popular majority." It might not be wrong to say that community based tourism is actually a transformative by this definition, however the challenges with it are paramount. The experiences have varied across the places over the success of community-based tourism. Contradicting views exist, for example, Scheyvens (2002) argues that the use of tourism to promote community development is a good concept in principle, but filled with difficulties in practice. Adding more to it, Pleumaron (2002) also cautioned of the dangers of igonoring precautionary measures before involving ignorant and untrained communities into new schemes, explaining that short-cut measures fail, leaving local people in jeopardy while program move on elsewhere. Thus, the question of proper implementation and closure of community-based tourism is a must.

In terms of conceptual devlopment CBT has gained high popularity, however in practice front CBT remains less researched, and there are less conclusive indicators of its success (Jugmohan, 2015). There are paramaount research needs in many areas in CBT (Hiwasaki, 2006), and issues for local community involvement in tourism development projects have been addressed (Sebele, 2010). The research focuses primarily on two communities based tourism endeavors at two different locations. These two places have implemented community-based tourism. Firstly, it will test the impact of CBT, both positive and negative in terms of parameters like enhancement of quality of life, improvement of cultural heritage etc. Then it checks whether CBT can create transformative effect or not to service provider, its employees and locality. Although the researches are conducted at two different locations of Nepal, this study's findings provide case for other similar programs around the globe. In addition, the positive results concerning community-based tourism will likely result in more of such programs initiation and will find prominent place in the society to uplift individuals as well as community. 


\section{Literature review}

Looking back to origin of community-based tourism (CBT), the emergence of CBT both in theory and practice have first been in developed counties for example in Canada witnessed community participation in tourism (Keogh, 1990), and then in the UK in Prentice (1993) and also Simmons (1994). Nevertheless, over the time, it has found more popularity in developing countries giving rise to majority of liteatures. Some of the examples are: Timothy's (1999) Indonesian participatory planning study, Li's (2006) study of China's community participation in tourism, Hipwell's (2007) study of Tiwanese community-based ecotourism (CBET), Al-Oun and Al-Homoud's (2008) study in Jordan, Sebele's (2010) study in Botswana, and many more that followed in recent time illustrate the rising interest in this concept. Thus, conclusively issues related to community development, empowerment, participation and poverty alleviation have been addressed by CBT as a tool over the years.

In (Wood \& Jones, 2008) words, "CBT projects are small or medium sized ventures that have the potential to create a list of positive social and economic development impacts in rural area, where other types of development may be inadequate". It suggests CBT as a unique concept with the ability to bring positive change and or impact in a place where other sorts of activities may be insufficient. Whereas (Nature, 2015) talks about community based tourism as a form of tourism where the local community controls and engages in its CBT development and management programs, and a major chunk of the benefits remain within the community itself. Such form of tourism provides natural, value-packed travel services that use local accommodation, food, music, art, crafts and traditions. It delivers best travel experience that supports sustainable development as well. CBT provide the national and international travelers genuine visit inside homes, village, and heritages and the earning generated is directly provided to the family those visitors stay with and buy services from.

In context of Nepal where rural society is predominant with rich ethnic and cultural diversity, community based rural tourism and homestays are included in CBT concepts. They are part of ecotourism and offers prospect for cultural immersion. Sirubari Village is a model village that hosted the idea of community based village tourism in Nepal and the Gurung indigenous people are main inhabitant of the village (Thakur, 2013). Recently, the concept of CBT has grown in popularity and is practiced widely in different ways in different parts of Nepal. There lacks consistent implementation of CBT projects around Nepal. (Magar, 2016) talks about CBT concept as built on the principle of living a local life in an authentic and grass-root way, providing immediate benefits to the people in the community itself. Travelers visit the homes of the community or other locally managed accommodation as part of CBT, buy locally-made products and use local tour operators to get the tour of 
various activities in the place. In doing so, travelers get to contribute to sustainable economies as well as experience Nepal being part of local communities.

\section{Transformative service research \& transformative effect}

Traditional service marketing research only identifies solution to the problems faced by management mostly related to the bottomline. However mproving consumer and societal well being through transformative service has recently been identified as one of the top ten key research priorities for service scholars (Ostrom et al., 2010). Service being very substantial part of people lives, 'Transformative Service Research' (TSR) is one of the emerging concepts of Service Industry. Conceptualized by Anderson (2010), TSR is regarded as any research that aims to figure out relationship between service industry and wellbeing without focusing on academic discipline. To bring about clarity "service research that centers on creating uplifting changes and improvements in the well-being of individuals (consumers and employees), families, social networks, communities, cities, nations, collectives, and ecosystems" (Anderson et al. 2011; Rosenbaum et al., 2011a, p.3).

Rising above the bottom line, TSR inspires researchers to explore such issues as social justice, consumer agency, and ecological stability and expands on contemporary concepts such as sustainability, green marketing, and the triple bottom line, emphasizing corporate responsibility for economic, social, and environmental outcomes of business practices (Ostrom et al., 2010). Furthermore, it demands for the development of new measures of the effects of service on individuals and societies. The dynamic nature of services offers substantial transformative potential because of the direct and often dialogic interaction between the service provider and the consumer (Anderson et al., 2011). Community based tourism as we looked from transformative service lens, attempt to deliver the same. However we focus on the transformative effect of CBT on local community, service provider and employees working for it.

As promoted by transformative service research, the transformation comes from the outcome where the participants could feel the sense of well being due to the engagement. The community-based tourism is designed to uplift the service provider, employees and the local community. These well being factors can be financial well being, community attachment, finding community best place to raise family, feeling about meaning of life and subjective well being.

\section{Community based tourism in Nepal}

Since mid-twentieth, one can see the rise in the social movement entitled with community development as fast-increasing industry (Vidal, 1997). Community based tourism is guided purely with the objective of recognizing and alleviating poverty in low-income and minority communities around the world, mostly relevant 
in developing countries. The essense of community development is for community members to come together and take collective actions to achieve all forms of collective well beings like economic, social, environmental and cultural wellbeing of the community (Buckley, 1999). On the inspiring note, United Nation (UN, 2000), came front to highlight the inter-relationship of eradication of poverty and community development in the Millennium Development Goals (MDGs) (Khadka, 2012). Amidst, all these changes, initiation of community based tourism with proper recognitation of its importance by government too, took place Nepal too. The challenges remained to fully utilize it and get the best outcome of it for the intended purpose of community development.

Amidst most of the wretched development results, tourism has emerged as one of the few promising sectors of the Nepalese economy, and if blessed with anything else, Nepal is endowed with beautywith potential to be one of the world's greatest tourist spectacles (Stevens, 1988). Tourism development in Nepal has been envisaged as a development tool in stimulating tourism growth as well as in reducing rural poverty. In context of Nepal, it is evident that poverty is widespread; its acuteness is even higher in the rural/ mountain areas. In many impending areas, tourism is accepted as a medium to employ local community in the higher yield areas by linking to commercial process, and marketing chain beyond borders (Pandey, 2003). Recognizing this advantage, the government of Nepal has given utmost precedence to promoting CBT and it has also been apparent that this kind of tourism can play a momentous role in the development (Pandey, 2013). With a clear understanding that, this is employment-generating industry, it is expected to solve not only the unemployment problems but also impact the overall wellbeing of the people and community. With these objectives in mind, the government in collaboration with both private sectors and local community has worked to develop community-based sustainable rural tourism with wider objectives of local upliftment and well being (Pandey 1996, 2003).

Nepal's Seventh Plan (1985-90) signifies the principal attempt to frame a distinct tourism program with a long-term forthcoming for equitable socio-economic distribution. Subsequently, this developed as one of the major intentions of the Eighth Plan (1992-97) and the Ninth Plan (1997-2002). Despite a well-intentioned plan, the ninth plan could not succeed to reach considerable constituent of the rural community, notably the impecunious of the poor and estranged groups. In reply to this, the then government attempted to deal with poverty through concurrent strategies: broad-based economic growth; social sector upgradation; and a set of aimed programs with both Tenth Plan (2002-2007) and Interim Plan (2008- 2010), giving a good emphasis to poorest of the poor and marginalized population. Moreover, in the new Tourism Policy 2008 and Tourism Vision 2020, the government formulated new 
directives to manage the issues of severe poverty, high unemployment, and economic and social penury and have planned a long-term perspective and twenty-year growth goals (HMG, 1997, 2002, 2003 and GON 2007, 2009). Consequently, to address the issues, the CBT took a momentum in a planned approach making it a relatively new paradigm for the Nepali tourism industry. Comprehending the benefits of tourism at community level, both the governmental and non-governmental organizations put their efforts in rural communities stressing on various ecotourism related activities which in fact provided noble frontier in the Nepali tourism history by strengthening local people to be part of community-based tourism intended to reduce poverty from rural areas (Pandey, 2013). It is indicative that community based tourism is actually a transformative by this definition, however the challenges with it is paramount. And the experiences have varied across the places over the success of community-based tourism (Tasci et al, 2013).

\section{Theoretical aspects/conceptual framework}

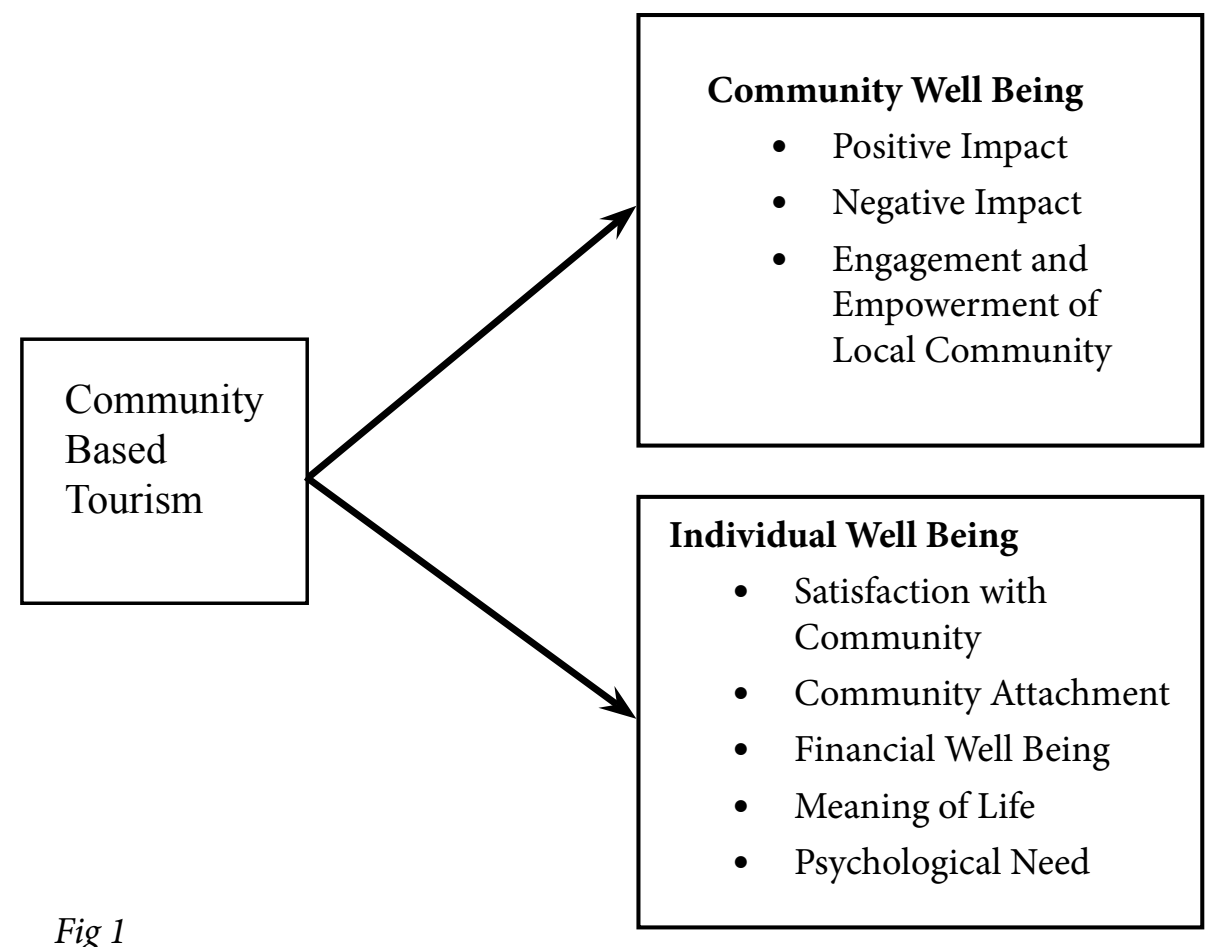

The framework explores the positive and negative impact of CBT in community in various parameters (e.g. tourist inflow, income increment, better schools, job increment, less migration of youth). Also, further it checks where CBT brings engagement and empowerment to local community or not. 
At the individual level, the study explores, whether CBT promotes individual well being for service providers and employees working for CBT in form of satisfaction with the community, community attachment, financial well being, meaning of life and psychological need.

In totality, the study checks whether CBT creates transformative effects in the life of the community, service providers and employees involved in it.

\section{Research methodology}

\section{Research questions}

The research questions this study addressed following questions:

1) What are the positive and negative impacts of CBT in the local community? Does the CBT promote engagement and empowerment in the local community?

2) Does CBT enhance satisfaction with the local community?

3) Does the community based tourism impact on the individual wellbeing as part of transformative effect (community attachment, sense of financial wellbeing, meaning of life and psychological needs)?

\section{Sample and procedure}

Community based tourism, wherever implemented in Nepal was the population for the study. This study used area based sampling method. After identifying the areas in Nepal, which implemented CBT, two places - Chitlang and Namobuddha were selected based on convenience. From these two places, three service providers and six people working on these community-based tourism locations involved in tourism business were randomly identified. Qualitative interviews were conducted with these participants of CBT. Along with the interview, for specific wellbeing measures (like financial well being, meaning of life, community attachment, satisfaction) standard and validated questionnaires were used to capture the emotions of the respondents. The study setting is non-contrived and the service providers and employee participants were the units of analysis. Trained interviewers conducted interviews. This study is a single cross-sectional study.

\section{Measures}

The semi structured qualitative interview questionnaire was developed based on the literature review and the objective of the study. As the questionnaires were prepared, there were pre-tested with expert and also participants to confirm the reliability of the questionnaire. The validated standard scales used were:

- Financial Well Being (CFPB Financial Well Being Scale) 
- Purpose of Life and Subjective Well Being (Steger's Meaning in Life, Ryan and Deci Basic Psychological Needs Scale

- Community Attachment and Satisfaction (Gene L. Theodori, 2001)

Results

CBT service provider's details and activities

CBT service provider 1: Namobuddha Resort

Short introduction \& CBT activities

Namo Buddha Resort is the first CBT provider in the area that provides quality services to the tourist visiting the resort. It opened in the year 2007, however from business point of view, it was officially started in the year 2010. The inflow of tourist was 3375 in 2013, 2606 in 2014 and 2074 in 2015. The resort is mainly targeted for the foreign expats that are the loyal customers of the resort and visit often to the place. The resort has yearly income of Rs.18-20 million.

\section{CBT service provider 2: local resort of Namobuddha}

Namo Buddha Resort only targeted international tourists and was considered costly for average Nepalese Traveler. There was no resort in Namobuddha targeting Nepalese Traveler. Hence a local resort started three months ago especially for Nepalese Traveler who wanted to spend some time at Namobuddha. The resort was located near to Namobuddha monastery and currently has seven rooms while alongside a fishpond and some cottages were being built. There was no clear information available from staff of resort about operations and earnings of resort. As per staff of resort, it has only been able to serve five customers per month since its inception.

\section{CBT service provider 3 - Chitlang Organic Village Resort}

It is the second CBT provider in Chitlang. It was started in 2010 by Mr. Debendra Nepal with support of his friends and has successfully completed 4 years adding more CBT providers and home stay to its service. The resort has monthly earning of NPR100, 000.00 from the CBT service. Travel agency is the source of income for the owner apart from CBT service. The resort provides additional services like village walk, cultural program and villager's interaction program for tourist.

\section{Community well-being}

\section{Assessment of positive impact of CBT}

Based on the interview with the three CBT service providers in Namo Buddha and Chitlang, the outcome is tabulated: 


\begin{tabular}{|c|c|c|c|c|}
\hline $\begin{array}{l}\text { CBT } \\
\text { Service } \\
\text { Provider }\end{array}$ & $\begin{array}{l}\text { Maintain and } \\
\text { strengthen } \\
\text { the quality of } \\
\text { life in local } \\
\text { communities }\end{array}$ & $\begin{array}{l}\text { Enhance the } \\
\text { historical heritage, } \\
\text { culture, traditions } \\
\text { etc. }\end{array}$ & $\begin{array}{l}\text { Enhance } \\
\text { quality of } \\
\text { landscape }\end{array}$ & $\begin{array}{l}\text { Supported } \\
\text { the } \\
\text { conservation } \\
\text { of natural } \\
\text { areas, } \\
\text { wildlife }\end{array}$ \\
\hline 1 & Yes & $\begin{array}{l}\text { Local cultural } \\
\text { activities (like } \\
\text { Jhankari and } \\
\text { traditional } \\
\text { dance) have been } \\
\text { appreciated by } \\
\text { tourist }\end{array}$ & Some level & No \\
\hline 2 & $\begin{array}{l}\text { Yes, to some } \\
\text { extent }\end{array}$ & $\begin{array}{l}\text { Yes (Same as } \\
\text { provider } 1 \text { ) }\end{array}$ & No & No \\
\hline 3 & Yes, a lot & $\begin{array}{l}\text { Many heritages } \\
\text { renovated } \\
\text { People are aware } \\
\text { and communicate } \\
\text { with archaeological } \\
\text { department }\end{array}$ & Not yet & Not yet \\
\hline $\begin{array}{l}\text { CBT } \\
\text { Service } \\
\text { Provider }\end{array}$ & $\begin{array}{l}\text { Support or } \\
\text { inspiration } \\
\text { to be part of } \\
\text { CBT } \\
\end{array}$ & Activities done & $\begin{array}{l}\text { Range of } \\
\text { services } \\
\text { provided }\end{array}$ & Changes seen \\
\hline 1 & $\begin{array}{l}\text { Realizing } \\
\text { the cultural } \\
\text { importance of } \\
\text { the place }\end{array}$ & $\begin{array}{l}\text { Organic production } \\
\text { and supply of } \\
\text { vegetables } \\
\text { Skills development } \\
\text { training }\end{array}$ & $\begin{array}{l}\text { Cultural } \\
\text { program } \\
\text { Village walk }\end{array}$ & $\begin{array}{l}\text { More tourist } \\
\text { inflow } \\
\text { Increase in } \\
\text { local agro } \\
\text { activities } \\
\text { Schools got } \\
\text { better } \\
\text { Increment in } \\
\text { no of jobs } \\
\text { Promotion of } \\
\text { the place }\end{array}$ \\
\hline
\end{tabular}




\begin{tabular}{|l|l|l|l|l|}
\hline 2 & $\begin{array}{l}\text { More tourist } \\
\text { inflow, road } \\
\text { development } \\
\text { of vegetables } \\
\text { Fishing }\end{array}$ & $\begin{array}{l}\text { Organic production } \\
\text { program } \\
\text { Celebrate } \\
\text { local } \\
\text { tradition }\end{array}$ & $\begin{array}{l}\text { Cultural } \\
\text { no of jobs } \\
\text { Income } \\
\text { increased }\end{array}$ \\
\hline 3 & $\begin{array}{l}\text { Support by } \\
\text { friends }\end{array}$ & $\begin{array}{l}\text { Agro activities, } \\
\text { Micro industry } \\
\text { practice }\end{array}$ & $\begin{array}{l}\text { Village walk } \\
\text { Cultural } \\
\text { program } \\
\text { Interaction } \\
\text { program }\end{array}$ & $\begin{array}{l}\text { More tourist } \\
\text { inflow } \\
\text { Promotion of } \\
\text { the place } \\
\text { Income } \\
\text { increased } \\
\text { Less } \\
\text { migration to } \\
\text { capita city } \\
\text { and abroad }\end{array}$ \\
\hline
\end{tabular}

Table 1

\section{Positive Impact of CBT in Namo Buddha and Chitlang}

Both at Namo Buddha and Chitlang, CBT promoted more inflow of tourists in the community. A significant increment in local employment was witnessed in Namo Buddha, as $80 \%$ of the resort staffs were from local community promoting jobs like local tour guide, local carpenter and construction workers. Chitlang has promotion of local place, increment in income and also decrement in migration of local residents. Also, another encouraging fact is CBT has increased local entrepreneurial activity, where in Namo Buddha 10 vegetables farm supplying to the resort organic vegetables, rainwater recharge points, local homestays, local lodges and guest house, small resort, local shops. Further, Namo Buddha saw increment in increment of job skills traininghousekeeping, organic gardening, cooking and service training to employed people and increase in development activities- local schools, road construction, picnic spots. In Chitlang too, local vegetables, fruits and cheese were promoted, and also tourists visited local villages during walk and generously donating gifts, money and ideas for improvements. Thus, CBT has brought tremendous positive impact in local economy and well-being.

Looking at other aspect, CBT has empowered women through job opportunity, enhanced local participation and involvement in tourism related activities in Namo Buddha. Also for local heritage, it has promoted monastery and stupa. In terms of local cultural heritage, the Tamang culture and tradition has been promoted, overall the Namo Buddha CBT providers feel that the introduction of CBT has enhanced the standard of living and quality of life, and has also led to decline of youth migration 
to Arabic countries. Chitlang CBT provider expressed similar experience with enhancement in standard of living and decline of youth migration to Arabic countries. In overall, CBT has been able to create social impact in both Namo Buddha and Chitlang.

In both places Namo Buddha and Chitlang it seems, the CBT has not contributed in maintain and enhance the quality of landscapes and avoid the physical and visual degradation of environment. Also, it has not played significant role in supporting the conservation of natural areas, habitats and wildlife, and minimize damage to them. Both of these are serious issue. CBT has been able to create significant economic and social impact, whereas when it comes to conservation and landscape, it has not contributed. There can be several reasons for this, first the CBT provider are not aware, or there is lack of proper mechanism to link CBT providers with these activities or there are adequate policy in place. Both of these require serious attention by concerned authorities.

\section{Negative impact of CBT in Namobuddha and Chitlang}

The CBT service providers expressed some negative aspects of CBT as well. First of all the CBT is creating garbage, which are not managed properly or rather no attention has been provided to these waste creation due to high inflow of tourists. Another factor pointed out is lack of proper understanding about CBT among local communities often leading to misunderstanding and local communities feel disturbed by all these CBT activities. One cannot deny the effect of CBT on local environment as well as negative outcomes of CBT, nevertheless all of these negative aspects are manageable, and also they demand serious attention by CBT provider and concerned authority.

\section{Engagement and empowerment of local community}

Despite the earlier results show that there are significant social and economic activity being promoted by CBT, yet, the engagement of local community in overall planning decision making about the management and future development of tourism in the area is not significant. The service provider feels this has not been attained by CBT. This is rather a concern as the whole essence of CBT is to practice communitybased development, for which necessary programs, structures and systems need to be installed to motivate maximum engagement of local community the management of local tourism.

\section{Individual Well Being}

In order to understand the impact of CBT on local people, questions were asked to express their views regarding their observation before CBT was initiated in their place and after CBT was established in their local area. 


\section{Satisfaction}

All the five interview participants found their local community as right place to raise their family, however they have not witnessed significant improvement in medical and health care services. The local schools more of less remain same. However, they seem to be satisfied with the youth programs and opportunity for senior citizens to earn an adequate income. They did not observe any improvement in local shopping facilities and recreation facilities and program. So the infrastructural development has not taken place. However all of them were satisfied with the overall physical appearance of the community.

This shows, that CBT has contributed in some areas like family raising environment, income generation for all and overall outlook of the place. But, CBT has not been able to bring change in areas like medical and health, local school local shopping facilities, recreation facilities and program.

\section{Community attachment}

The community attachment was found to be extremely strong. Some of responses were "It's our ancestors place we cannot imagine leaving it for any reason". "I was born here and I spent most part of my life here itself. I will be very sad if I have to leave this place". "Though I would be able to make more money than here if I leave this place but how can someone leave their ancestors for sake of money". All of them expressed they will be very sorry to leave. Based on their expression the attachment is more due to their ancestors' relationship and being their birthplace, rather than from CBT activities. Irrespective it is encouraging for CBT programs, which local people are attached to their community and migration is not their preferred choice. If CBT could provide opportunities, local people will choose to remain in their local community. Another encouraging thing is all the local people were highly interested in their community activities and programs, they were curious to know what is going on. This is a positive sign.

\section{Financial well-being}

In order to assess the impact on financial well being of both local people engaged in CBT and CBT service providers, questions were asked to express their opinion regarding their experience after being engaged in the CBT.

When asked about financial well-being, there are mixed answers, but all the answers are above average score.

\begin{tabular}{|l|c|}
\hline \multicolumn{1}{|c|}{ Financial Well Being } & On Scale $\mathbf{1}$ to 5 \\
\hline I could handle a major unexpected expense & 2.75 \\
\hline I am securing my financial future & 2.75 \\
\hline
\end{tabular}




\begin{tabular}{|l|c|}
\hline $\begin{array}{l}\text { Because of my money situation, I feel like I will never } \\
\text { have the things I want in life }\end{array}$ & 2.88 \\
\hline $\begin{array}{l}\text { I can enjoy life because of the way I'm managing my } \\
\text { money }\end{array}$ & 3.75 \\
\hline
\end{tabular}

Table 2

As shown above, people are able to enjoy life by managing their money, which is a positive outlook. Other measures are also good and above average. Also, the CBT service providers are happier with their financial well-being.

\section{Purpose of life and subjective well-being}

Both the CBT service provider and employees in CBT were asked questions about their view about their meaning of life after being associated with the communitybased tourism. The results are as shown below:

\begin{tabular}{|l|c|}
\hline \multicolumn{1}{|c|}{ Meaning of Life } & Mean (Scale 1 to 5) \\
\hline My life has a clear sense of purpose & 2.88 \\
\hline I have a good sense of what makes my life meaningful & 2.75 \\
\hline I have discovered a satisfying life purpose & 3.00 \\
\hline & $\mathbf{2 . 8 8}$ \\
\hline
\end{tabular}

Table 3

The result shows that the CBT is keeping people positive, the in upper side of the mid-point, that indicates the score is above average, thus the participants have positive outlook towards the life.

Furthermore, questions were asked regarding the psychological needs to the CBT service providers and employees. As they were asked to rate, the results are shown below:

\begin{tabular}{|l|c|}
\hline Autonomy & Mean (Scale 1 to 5) \\
\hline I feel like I am free to decide for myself how to live my life & 3.25 \\
\hline I generally feel free to express my ideas and opinions & 3.25 \\
\hline I feel like I am pretty much be myself in daily situations & 2.88 \\
\hline & $\mathbf{3 . 1 3}$ \\
\hline Competence & \\
\hline People I know tell me I am competent at what I do & 3.38 \\
\hline Most days I feel a sense of accomplishment from what I do & 3.13 \\
\hline I often feel very capable & 2.75 \\
\hline
\end{tabular}




\begin{tabular}{|l|c|}
\hline Relatedness & \\
\hline I get along with people I come into contact with & 3.25 \\
\hline $\begin{array}{l}\text { I consider the people I regularly interact with to be my } \\
\text { friends }\end{array}$ & 2.75 \\
\hline People in my life care about me & 3.38 \\
\hline & $\mathbf{3 . 1 3}$ \\
\hline
\end{tabular}

Table 4

In all three constructs, autonomy, competence and relatedness, the respondents have given score higher than average, which is positive. Thus getting engaged in the CBT has fulfilled psychological needs of both the service providers and employees working in CBT.

\section{Discussion}

The study has explored the transformative effect of community-based tourism in the local tourism. The study shows that CBT has been successful in stimulating local economy in terms of tourist in flow, enhance the historical heritage, culture, traditions etc., promoting local tradition, generating income promoting local entrepreneurship and produces. The economic impact of CBT is found to be significant. Other researches show that the impact of tourism is measured by taking into considering two vital elements (Nyaupane et al., 2006): firstly, the level of engagement and control of locals in tourism; and secondly, the number and the profile of tourists visiting the designated area. In these two factors, the first one is not found to be effective in two CBT under study, but the second one has been quite successful. Furthermore, tourism can have very positive consequences, such as promoting the preservation of local culture, the re-establishment of partially lost cultural constituents and the assembly of pride in the past (Al-Oun and Al-Hamoud, 2008). All these are visible from the study of two CBTs in question.

The study shows in the CBTs taken consideration, that local empowerment and engagement in the overall planning and development of tourism is not high. At the same time in the negative impact, people feel disturbed by CBT. This is consistent with findings by Irandu (2004), which pointed to the fact that reaction towards tourists is impacted by the involvement in the tourism development affair, and the extent to which the community endowed with the economic benefits of tourism. And those communities that are dependent on tourists are likely to show lesser amount of exasperation. There are some other theories about attitudes of community attitudes towards local tourism (Dogan, 1989; Ap \& Crompton, 1993), which also show a continuum from acceptance to resistance. The same is seen in our study, and this is one way to reduce the local resistance to community tourism. 
This study shows that the CBT has not been able to get local participation, which is not rare. Other researchers have also revealed restraint to engagement of the local community, such as absence of knowledge and resources, and the fact that the local community have difficulty operate as one group (Koch, 1997; Tosun, 2000; Scheyvens, 2002). Similar problem also persists here in terms of broader and deeper local participation. In the two studied CBTs, the engagement an empowerment of the local community is lacking, which is common issue. Thus, in some way this needs to be rectified.

The study shows that the people involved in CBT have better individual wellbeing. They are satisfied with their life and exhibit better community attachment. In terms of financial wellbeing and psychological needs, CBT seems to fulfill these requirements. Thus, all the ratings expressed by the participants are more than average. The results reported are consistent with previous research findings (Kim, 2002). In line with this finding, Crotts and Holland (1993) synopsized that tourism has an affirmative influence on the quality of life of rural populations. In another study, Perdue, Long and Gustke (1991) also examined the relationship between tourism and quality of life of local citizen. They summed up that tourism has an influence on various factors that enhances the quality of life for locals like type of employment generation, educational cost and quality and health services provision. Similar outcome are registered by the two CBTs taken in account by this study. Therefore, this study concludes that tourism has the positive effect on quality of life (well-being).

The study shows CBT remains important in circumstances where communities have natural, human and physical blessings and foundations, which is ample in Nepali community. It further concludes that strenght of the community leadership and robustness of community cohesion within the community, and the infrastructure and touristic attractions available in the community, CBT ventures can be initiated for mutual and common transformative benefit of individual and the community (Giampiccoli \& Mtapuri, 2017). However, it can be concluded that, though two CBTs studied here have rooms for improvements in terms of implementation and coverage of impact, the have created positive impact on both community and individual well being. Their establishment and promotion can be set as priority by tourism governing body. However, in the implementation part, proper mechanism, scope of coverage, local engagement and empowerment should be ensured for best results. Conclusively, in developing countries like Nepal, CBT is one of the activities brought in by national and international community to uplift livelihood of the places, and this study shows CBT to be a right solution for community development and can have transformative effect on individual, community and society as a whole. 


\section{Limitation and suggestions for future research}

This study has several limitations that need to be addressed in future research. First, all the study variables were captured by asking questions, and therefore interviewer's bias cannot be ruled out. Second, the small sample drawn from only two CBT implemented places restrict the representativeness of the sample. Nonetheless, the findings of this study are in line with the findings of the studies carried out in different cultural contexts settings.

Findings of this study suggest several avenues for further research. In this study, sample was drawn from two places so future study can be conducted in larger population for the better generalizability. In addition, future studies could examine influence of CBT on service consumer. Future studies could also examine the moderating effect of other variables like policy intervention, private participation etc. on the relationship.

\section{References}

Al-Oun, S., \& Al-Homoud, M. (2008). The potential for developing communitybased tourism among the Bedouins in the Badia of Jordan. Journal of Heritage Tourism, 3(1), 36-54.

Anderson, Laurel, Amy L. Ostrom, and Mary Jo Bitner (2011), "Surrounded by Services: A New Lens for Examining the Influence of Services as Social Structures on Wellbeing," working paper, W. P. Carey School of Business, Arizona State University.

Anderson, L., Ostrom, A.L (2015). Transformative Service Research Advancing Our Knowledge About Service and Well Being. Journal of Service Research, 18(3), 243-249.

Ap, J., \& Crompton, J. L. (1993). Residents' strategies for responding to tourism impacts. Journal of travel research, 32(1), 47-50.

Brohman, J, (1996) New Directions in Tourism for the Third World, Annals of Tourism Research, 23(1):48-70:60

Buckley, R. P. (1999). International capital flows, economic sovereignty and developing countries. YB Int'l Fin. \& Econ. L., 4, 17.

Crotts, J. C., \& Holland, S. M. (1993). Objective indicators of the impact of rural tourism development in the state of Florida. Journal of Sustainable Tourism, 1(2), 112-120.

Davis, B., Ozanne, J. L., \& Hill, R. P. (2016). The Transformative Consumer Research Movement. Journal of Public Policy \& Marketing, 35(2), 159-169.

Dogan, H.Z. (1989). Forms of Adjustment: So- ciocultural Impacts of Tourism. Annals of Tourism Research. 16(2), 216-136. 
Giampiccoli, A., \& Mtapuri, O. (2017). Role of external parties in Community-Based Tourism development: Towards a new model. African Journal of Hospitality, Tourism and Leisure. 6. 1-12.

Goodwin, Harold dan Rosa Santilli. 2009. Community-Based Tourism: A Success? ICRT Occasional Paper 11. http://www.andamandiscoveries.com. 20 Februari 2013.

Goodwin H (2006) Community-based tourism: Failing to Deliver? ID21 Insights, Issue \#62

Hipwell, W. T. (2007). Taiwan aboriginal ecotourism Tanayiku Natural Ecology Park. Annals of Tourism Research, 34(4), 876-897.

Hiwasaki, L. 2006. Community-based tourism: a pathway to sustainability for Japan's protected areas. Society \& Natural Resources: An International Journal, 19(8):675692.

Jugmohan, S. (2015). Pre-conditions, challenges and opportunities for community-based tourism in Mpondoland in the Eastern Cape Province of South Africa (Doctoral dissertation, Cape Peninsula University of Technology).

Keogh, B. (1990). Public participation in community tourism planning. Annals of Tourism Research, 17(3), 449-465.

Kim, K. (2002). The effects of tourism impacts upon quality of life of residents in the community (Doctoral dissertation, Virginia Polytechnic Institute and State University).

Khadka, R. (2012). Switching Gears: From Needs to Assets Based Approach to Community Development in Nepal. OIDA International Journal of Sustainable Development, 3(11), 81-88.

Koch, E. (1997). A vision of tourism for the New Southern Africa: Why tourism matters. Action for Southern Africa's People-First Tourism Campaign.

Li, W. J. (2006). Community decision making: Participation in development. Annals of Tourism Research, 33(1), 132-143.

Magar, T. T. (2016, august). Enjoy a Community based tourism holiday in Nepal. Retrieved from nepalhiking.com: http://www.nepalhiking.com/blog/enjoy-acommunity-based-tourism-holiday-in-nepal

Mick, David Glenn, Simone Pettigrew, Cornelia Pechmann, and Julie L. Ozanne (2012), "Origins, Qualities, and Envisionments of Transformative Consumer Research," in Transformative Consumer Research: For Personal and Collective Well-Being, David Glen Mick, Simone Pettigrew, Cornelia Pechmann, and Julie L. Ozanne, eds. New York: Routledge, 3-24. 
Mick, D. G. (2006). Meaning and mattering through transformative consumer research. Advances in Consumer Research, 33(1), 1-4.

Mitchell J \& Muckosy P (2008) A misguided quest: Community-based tourism in Latin America ODI Opinion 102

Nature, W.-w. f. (2015). What is CBT? Retrieved from cbtkyrgyzstan.kg.

Nyaupane, G. P., Morais, D. B., \& Dowler, L. (2006). The role of community involvement and number/type of visitors on tourism impacts: A controlled comparison of Annapurna, Nepal and Northwest Yunnan, China. Tourism management, 27(6), 1373-1385.

Ostrom, Amy L., Mary Jo Bitner, Stephen W. Brown, Kevin A. Burkhard, Michael Goul, Vicki Smith-Daniels, Haluk Demirkan, and Elliot Rabinovich (2010), "Moving Forward and Making a Difference: Research Priorities for the Science of Service," Journal of Service Research, 13 (1), 4-36.

Pandey, R.J. (1996), Rural tourism: A special concept, The Kathmandu Post, Vol. IV, No. 167.

Pandey, R.J. (2003), Rural Tourism Embraces Sustainability and the Poor, Sustainability: The Lasting Fuel for Sustainable Development - Nepal, 2003.

Pandey, R. J. (2013). Capacity Building and Human Resource Development Initiatives: Community Based Tourism Development in Nepal. Nepal Tourism and Development Review, 1(1), 83-101.

Perdue, R. R., Long, P. T., \& Kang, Y. S. (1999). Boomtown tourism and resident quality of life: The marketing of gaming to host community residents.Journal of Business Research, 44(3), 165-177.

Pleumaron, A. 2002. Community-based tourism: miracle or menace. Paper presented at the IYE Regional Conference on Community-Based Ecotourism in Southeast Asia, Chiang Mai, Thailand, 3-7 March 2002.

Prentice, R. (1993). Community-driven tourism planning and residents' preferences. Tourism Management, 14(3), 218-227.

Rosenbaum, M.S., Corus, C., Ostrom, A.L., Anderson, L., Fisk, R.P., Gallan, A.S. Giraldon, M., Mendes, M., Mulders,M., Rayburn, S.W., Shirahada, K. and Williams, J.D. (2011), "Conceptualization and aspirations of transformative service research", The Journal of Consumer Research, Vol. 19 pp. 1-6.

Scheyvens, R. 2007. Exploring the tourism-poverty nexus. Current Issues in Tourism, 10(2-3):231- 254 . 
Sebele, L. S. (2010). Community-based tourism ventures, benefits and challenges: Khama Rhino Sanctuary Trust, Central District, Botswana. Journal of Tourism Management, 31(1), 136-146.

Simmons, D. G. (1994). Community participation in tourism planning. Tourism Management, 15(2), 98-108.

Spenceley, A., \& Meyer, D. (2012). Tourism and Poverty Reduction: Theory and Practice in Less Economically Developed Countries. Journal of Sustainable Tourism. 20. 297-317. 10.1080/09669582.2012.668909.

Stevens, S. (1988). Tourism and development in Nepal.Kroeber Anthropological Society Papers, 67(68), 67-80.

Timothy, D. J. (1999). Participatory planning: A view of tourism in Indonesia. Annals of Tourism Research, 26(2), 371-391.

Thakur, M. R. K. (2013). Community Based Village Tourism in Nepal: A Case Study of Sirubari Village, Nepal (Doctoral dissertation, The Global Open University).

Tasci, A. D., Semrad, K. J., \& Yilmaz, S. S. (2013). Community Basted Tourism: Finding the equilibrium in the COMCEC context. COMCEC Coordination Office.

Tosun, C. (2000). Limits to community participation in the tourism development process in developing countries. Tourism management, 21(6), 613-633.

United Nations World Tourism Organisation (UNWTO). 2011. Moodie Report. Available at: http://www.moodiereport.com / document. Php? c_id = 6 \& doc_id $=27760$ [30 April 2013].

United Nations World Tourism Organization (UNWTO). 2013. UNWTO annual report 2012. Madrid: WTO.

Vidal, A. C. (1997). Can Community Development Re-Invent Itself?: The Challenges of Strengthening Neighborhoods in the 21st Century. Journal of the American Planning Association, 63(4), 429-438. 